\title{
Real Earnings Management and Industry Differences: Based on Empirical Evidence From Listed Companies in China
}

\author{
Xuexin $\mathrm{Bao}^{1}$ \\ ${ }^{1}$ School of Shipping and Naval Architecture, Chongqing Jiaotong University, Chongqing, China \\ Correspondence: Xuexin Bao, School of Shipping and Naval Architecture, Chongqing Jiaotong University, \\ Chongqing, China.
}

Received: May 2, 2020

Accepted: June 3, 2020

Online Published: June 19, 2020

doi:10.5430/ijba.v11n4p30

URL: https://doi.org/10.5430/ijba.v11n4p30

\begin{abstract}
This article examines the industry differences in the real earnings management behavior of listed companies in China. The study finds that listed companies in the health and social work industries have the highest degree of real earnings management, and the electricity, heat, gas and water production and supply industries has the lowest level of real earnings management, and there are obvious industry differences in real earnings management among Chinese listed companies. The empirical evidence in this paper shows that there are industry differences in the real earnings management of Chinese listed companies.
\end{abstract}

Keywords: real earnings management, industry differences, Chinese listed companies

\section{Introduction}

The promulgation of the Sarbanes-Oxley Act inhibited the manipulation of surplus by listed companies and protected the legitimate interests of market investors, but it also had some negative effects. On the one hand, the introduction of the Sarbanes-Oxley Act increases market supervision and also increases the external audit costs of listed companies, forcing many listed companies to choose to list on capital markets outside the United States. On the other hand, the Sarbanes-Oxley Act also triggered a dispute over whether the capital market is market supervision or legal supervision. However, it must be noted that after the introduction of the Sarbanes-Oxley Act, the accrued earnings management behavior of US listed companies that manipulated earnings through accounting reports did produce a significant decline (Cohen et al, 2008). However, with the decrease in the degree of manipulation of accrued earnings management of listed companies, some listed companies in order to achieve their own purposes turned to "real earnings management" instead, which is not easily discovered. To achieve their own earnings management, listed companies can mislead market investors by manipulating timing trading activities such as operations, fundraising, and financing. Moreover, theses real earnings management activities are less constrained by the flexibility of corporate accounting (Cai Chun et al., 2011), it is not easy to be discovered by external audits and other regulations, so after the Sarbanes-Oxley Act, real earnings management became the first choice for more listed companies to manipulate earnings.

Listed companies in different industries will show different characteristics. For example, in terms of asset structure, level of shareholder embezzlement, company performance, estimated earnings and shareholder reductions, there are industry characteristics (Guo Pengfei and Sun Peiyuan, 2003; Guo Pengfei and Yang Chaojun, 2003; Lin Chaonan et al., 2006; Cao Guohua and Lin Chuan, 2013). That means, due to differences in business operations, listed companies in different industries show great differences in many company characteristics. It is precisely the differences in the characteristics of these companies that have led to different decisions made by listed companies during their operations, such as choosing different forms of cash dividends (Quan Xiaofeng et al., 2010) and cash holdings (Zhou Jian Etc., 2009) and R \& D investment (Jin Ying, 2011), etc. Similarly, it is precisely because of the differences in characteristics and decision-making differences of listed companies in different industries that naturally lead to be different when making earnings management decisions, because listed companies in different industries have different capabilities to manipulate earnings and need to obtain the results of earnings management vary. Chen Wuchao (2013) found that listed companies in different cyclical industries have different levels of 
earnings management; Hu Yongping and Luo Jianke (2010) found that the methods and degree of earnings management of listed companies in different industries during the IPO process; Zhou Xiafei and Zhou Qianglong (2014) also found that the difference in the degree of competition in the industry has caused listed companies in highly competitive industries to require a higher degree of earnings management. It can be seen that there are gaps in the manipulation of earnings management of listed companies in different industries. However, most of the existing literature is mainly for the test of accrued earnings management of listed companies, but it ignores the industry differences at the level of real earnings management. Although, for example, Li Bin et al. (2009) and Wang Liangliang (2013) all considered the influence of industry factors on real earnings management, they also controlled the influence of industry differences on empirical testing in the form of control variables, but they did not report the specific impact of industry factors. Therefore, this article analyzes the real earnings management behavior of listed companies from the perspective of industry differences, which can help us to understand the differences in the real earnings of listed companies in different industries, and also help us better observe the convergence of the real earnings of listed companies. It is an important guiding significance for theoretical expansion and supervision practice. In addition, considering that the China Securities Regulatory Commission made corresponding amendments to the industry distribution standards of Chinese listed companies in 2012, under the new industry distribution standards, how the industry differentiation characteristics of the listed companies' real earnings management are also concerned.

\section{Research Design}

\subsection{Industry Classification Standard}

Clarke (1989), Guenther, Rosman (1994), Kahle and Walkling (1996) pointed out that scientific industry classification standards are the prerequisite for testing the different characteristics of listed companies in different industries, because different industry classification standards will affect the research variables. The significance level will lead to differences in empirical results, and resulting in differences in research results as well. The industry classification standards commonly used in Western securities markets mainly include the United Nations International Standard Industry Classification ISIC, the North American Industry Classification Standard (NAICS), and Morgan Stanley's Global Enterprise Industry Classification Standard (GICS). The relatively scientific industry classification standards in China are based on the "Guidelines for Industry Classification of Listed Companies" which issued by the China Securities Regulatory Commission (CSRC). This is the official industry standard for listed companies in China and the industry classification standard mainly used in domestic literature. The CSRC's industry classification standards are based on the "National Economic Industry Classification" of the Bureau of Statistics, and adds the corresponding classifications based on the homogeneity of production products. In 2012, to standardize the industry classification of listed companies, the CSRC revised China's listing in accordance with the laws and regulations of the "Statistics Law of the People 's Republic of China", "Statistical Management Measures for the Securities and Futures Market", and "National Economic Industry Classification". Therefore, referring to the literature that has studied the industry characteristics of listed companies and the corresponding regulations of the CSRC, this article uses the 2012 Guidelines for Industry Classification of Listed Companies as the industry classification standard.

According to the "Guidelines for Industry Classification of Listed Companies" revised in 2012, the principles for industry classification of listed companies in China are: a. The main classification criteria and basis are financial data such as the operating income of listed companies, and the financial data used are the consolidated statement data audited by the accounting firm and publicly disclosed; $b$. When the operating income ratio of a certain business of a listed company is greater than or equal to $50 \%$, it is classified into the industry corresponding to the business; c. When a listed company does not have a type of business whose operating income ratio is greater than or equal to $50 \%$, but the income and profit of a certain type of business are the highest in all businesses, and they account for more than $30 \%$ of the company's total revenue and total profit (including the number), The company belongs to the industry category corresponding to the business; $\mathrm{d}$. If the industry attribution cannot be determined according to the above classification method, the industry classification expert committee of the listed company shall judge the company's industry attribution according to the actual operating status of the company; if the attribution is not clear, it shall be classified as a comprehensive category. According to the corresponding classification principles, Chinese listed companies are divided into 19 categories, 90 major categories and 288 medium categories. 


\subsection{Real Earnings Management}

Referring to the model of Roychowdhury (2006) and Li Bin et al. (2009), combined with the changes in the measurement indicators in the financial statements of listed companies after the new accounting standards, this article uses the method of estimating coefficients by industry, first of all, sales manipulation (ACFO) and expense manipulation (AEXP) and production control (APROD) are calculated respectively, and then the total earning degree of real earning management is determined by:

$$
\begin{gathered}
A C F O_{t}=\frac{C F O_{t}}{A_{t-1}}-\left(\begin{array}{l}
\alpha_{1} \frac{S_{t}}{A_{t-1}}+\alpha_{2} \frac{\Delta S_{t}}{A_{t-1}}+\alpha_{3} \frac{\Delta S_{t-1}}{A_{t-1}}+\alpha_{4} \frac{T C_{t}}{A_{t-1}}+\alpha_{5} \frac{E C_{t}}{A_{t-1}} \\
+\alpha_{6} \frac{O C_{t}}{A_{t-1}}+\alpha_{7} \frac{1}{A_{t-1}}+C
\end{array}\right) \\
A E X P_{t}=\frac{D I S E X P_{t}}{A_{t-1}}-\left(\alpha_{1} \frac{S_{t-1}}{A_{t-1}}+\alpha_{2} \frac{1}{A_{t-1}}+C\right) \\
A P R O D_{t}=\frac{P_{R O D}}{A_{t-1}}-\left(\alpha_{1} \frac{S_{t}}{A_{t-1}}+\alpha_{2} \frac{\Delta S_{t}}{A_{t-1}}+\alpha_{3} \frac{\Delta S_{t-1}}{A_{t-1}}+\alpha_{4} \frac{1}{A_{t-1}}+C\right)
\end{gathered}
$$

In the above formula, CFO obtains net cash flow for operations, DISEXP is the sum of operating costs and management expenses, and PROD is after the change in sales expenses and year-end and year-end inventory. Among other variables, $\mathrm{S}$ is the operating income, TC is the taxes and fees paid, EC is paid to employees and cash paid for employees, $\mathrm{OC}$ is other cash paid related to operating activities, $\mathrm{A}$ is the total assets, and $\Delta$ is the changes from the beginning of the year to the end of the year, $\mathrm{t}$ and $\mathrm{t}-1$ are the end and the beginning of the period, respectively, and $\mathrm{C}$ is a constant term that adjusts the model. For the coefficient value $\alpha$ to be solved, the regression model constructed by the following formula is used to estimate by industry:

$$
\begin{gathered}
\frac{C F O_{t}}{A_{t-1}}-\left(\begin{array}{l}
\beta_{1} \frac{S_{t}}{A_{t-1}}+\beta_{2} \frac{\Delta S_{t}}{A_{t-1}}+\beta_{3} \frac{\Delta S_{t-1}}{A_{t-1}}+\beta_{4} \frac{T C_{t}}{A_{t-1}}+\beta_{5} \frac{E C_{t}}{A_{t-1}}+\beta_{6} \frac{O C_{t}}{A_{t-1}} \\
+\beta_{7} \frac{1}{A_{t-1}}+C+\varepsilon
\end{array}\right) \\
\frac{D I S E X P_{t}}{A_{t-1}}=\beta_{1} \frac{S_{t-1}}{A_{t-1}}+\beta_{2} \frac{1}{A_{t-1}}+C+\varepsilon \\
\frac{P R O D_{t}}{A_{t-1}}=\beta_{1} \frac{S_{t}}{A_{t-1}}+\beta_{2} \frac{\Delta S_{t}}{A_{t-1}}+\beta_{3} \frac{\Delta S_{t-1}}{A_{t-1}}+\beta_{4} \frac{1}{A_{t-1}}+C+\varepsilon
\end{gathered}
$$

According to the regression model above, we can find out the value $\beta$, which leads to the value $\alpha$ that needs to be solved. On this basis, the real earnings management value $(\mathrm{RM})$ of listed companies is:

$$
R M_{t}=A C F O_{t}+A E X P_{t}+A P R O D_{t}
$$

\subsection{Research Method}

First, this paper chooses the Kuskal-Wallis $\mathrm{H}$ method in the non-parametric test to test whether there is a difference in the degree of true earnings management among listed companies in different industries. Since this test method does not require the sample to meet the preconditions of normal distribution or equal variance, it has better applicability (Scott and Martin, 1975). 
Secondly, on the basis of non-parametric tests, in order to more formally and better test the strength of industry factors' interpretation of real earnings management, this article will use the industry categories of listed companies as dummy variables and conduct corresponding multiple regression tests to test Whether the explanatory strength of industry factors exists, the specific test model is:

$$
\left|R M_{i, t}\right|=\left(\begin{array}{l}
\sum \alpha_{i} I_{i, t}+\beta_{1} \ln \left(\text { Size }_{i, t}\right)+\beta_{2} R O A_{i, t}+\beta_{3} \text { Debt }_{i, t}+\beta_{4} H 10_{i, t} \\
+\beta_{5} F n_{i, t}+C+\varepsilon_{i, t}
\end{array}\right)
$$

In Equation 8, the variable I is a dummy variable set according to the industry category of the sample listed companies. Considering the setting rules of the dummy variable and the established habits of the industry difference research literature, this article chooses to list the manufacturing industry Companies are set as the benchmark category, and listed companies in other industries are set as the comparative category. Other variables refer to the control variables set by reference to relevant researches of Roychowdhury (2006), Li Bin et al. (2009), Li Wanli et al. (2011), and the specific variables are defined as:

Asset capacity (Size): Measured according to the total assets value of the sample listed company $i$ at the end of t year, and take the natural logarithm $(\ln ($ Size $))$

Profitability (ROA): measured by the value of the return on assets of the sample listed company $i$ at the end of year $t$;

Debt capacity (Debt): measured by the value of the asset-liability ratio of the sample listed company $i$ at the end of year t;

Equity concentration ability (H10): Measured according to the Herfindahl_10 index value of the sample listed company $i$ at the end of $t$ year, the sum of squared shares held by the top ten shareholders of the listed company at the end of the year;

Financing capacity (Fn): measured by the dummy variable of the sample listed company i 's net cash flow value of financing activities at the end of year $t$, which means if the net cash flow value of financing activities is more than the sum of net cash flow from operating activities and net cash flow from investment activities If it is large, Fn $=1$, otherwise set $F n=0$.

\section{Statistics on the Real Earnings Management of Listed Companies in Different Industries}

Table 1. Statistics on the real earnings management of listed companies in different industries (overall)

\begin{tabular}{|c|c|c|c|c|}
\hline \multirow[b]{2}{*}{ Industries } & \multicolumn{4}{|c|}{$2007-2014$} \\
\hline & $\mathrm{N}$ & $\begin{array}{l}|\mathrm{RM}| \\
\text { Average }\end{array}$ & $\begin{array}{l}|\mathrm{RM}| \\
\text { Maximum }\end{array}$ & $\begin{array}{l}|\mathrm{RM}| \\
\text { Minimum }\end{array}$ \\
\hline Agriculture, Forestry, Animal Husbandry, and Fishery (A) & 189 & 0.227 & 2.981 & 0.001 \\
\hline Mining (B) & 358 & 0.379 & 8.255 & 0.003 \\
\hline Manufacturing (C) & 6621 & 0.341 & 8.266 & 0 \\
\hline Electricity, Heat, Gas and Water Production and Supply (D) & 542 & 0.226 & 2.795 & 0 \\
\hline Construction Industry (E) & 312 & 0.324 & 4.367 & 0.001 \\
\hline Wholesale and Retail (F) & 920 & 0.517 & 8.998 & 0.001 \\
\hline Transportation, Warehousing And Logistics (G) & 367 & 0.239 & 5.072 & 0 \\
\hline Accommodation and Catering $(\mathrm{H})$ & 58 & 0.487 & 1.577 & 0.005 \\
\hline $\begin{array}{l}\text { Information Transmission, Software and Information Technology } \\
\text { Services (I) }\end{array}$ & 365 & 0.329 & 3.725 & 0 \\
\hline Real Estate (K) & 859 & 0.313 & 6.304 & 0 \\
\hline Leasing and Business Services (L) & 115 & 0.335 & 2.271 & 0.003 \\
\hline
\end{tabular}




\begin{tabular}{lllll}
\hline Scientific Research and Technical Services (M) & 28 & 0.265 & 0.736 & 0.001 \\
\hline Water, Environment and Public Facilities Management (N) & 112 & 0.27 & 3.133 & 0.002 \\
\hline Education (P) & 8 & 0.279 & 0.418 & 0.057 \\
\hline Health and Social Work (Q) & 15 & 0.698 & 2.161 & 0.004 \\
\hline Culture, Sports and Entertainment (R) & 131 & 0.353 & 3.874 & 0.001 \\
\hline Others(S) & 174 & 0.305 & 3.415 & 0.002 \\
\hline
\end{tabular}

Table 1 shows the statistical status of the real earnings management industry average of the sample overall. Among them, the listed companies in the health and social work (Q) industries have the highest degree of real earnings management, but the sample size of the industry is small, indicating that a higher degree of real earnings management of individual listed companies promotes the increase in the degree of real earnings management of the entire industry; The real earnings management degree of listed companies in the wholesale and retail $(\mathrm{F})$ industries, and the real earnings management degree of listed companies in the accommodation and catering $(\mathrm{H})$ industries, both exceeds 0.4. The listed companies in the electricity, heat, gas and water production and supply (D) industries have the lowest true earnings management, followed by the listed companies in the agriculture, forestry, animal husbandry, and fishery (A) industries, followed by transportation. The average earnings management degree of listed companies in the transportation, warehousing and logistics $(G)$ industries does not exceed 0.25 . The average earnings management of listed companies in other industries is relatively concentrated, ranging from 0.25-0.40. From the perspective of the highest value of real earnings management of listed companies in various industries, the highest value appeared in the wholesale and retail $(\mathrm{F})$ industries, which were 8.998.

Table 2. Statistics on the real earnings management of listed companies in different industries (each year)

\begin{tabular}{|c|c|c|c|c|c|c|c|c|c|c|c|c|c|c|c|c|}
\hline & 2007 & & 2008 & & 2009 & & 2010 & & 2011 & & 2012 & & 2013 & & 2014 & \\
\hline & $\mathrm{N}$ & $|\mathrm{RM}|$ & $\mathrm{N}$ & $|\mathrm{RM}|$ & $\mathrm{N}$ & $|\mathrm{RM}|$ & $\mathrm{N}$ & $|\mathrm{RM}|$ & $\mathrm{N}$ & $|\mathrm{RM}|$ & $\mathrm{N}$ & $|\mathrm{RM}|$ & $\mathrm{N}$ & $|\mathrm{RM}|$ & $\mathrm{N}$ & $|\mathrm{RM}|$ \\
\hline A & 17 & 0.378 & 20 & 0.175 & 21 & 0.166 & 22 & 0.117 & 23 & 0.267 & 27 & 0.315 & 29 & 0.277 & 30 & 0.144 \\
\hline B & 31 & 0.808 & 36 & 0.309 & 41 & 0.251 & 33 & 0.224 & 46 & 0.425 & 49 & 0.515 & 54 & 0.427 & 57 & 0.204 \\
\hline $\mathrm{C}$ & 578 & 0.835 & 625 & 0.236 & 693 & 0.29 & 724 & 0.279 & 764 & 0.4 & 964 & 0.264 & 1105 & 0.375 & 1167 & 0.217 \\
\hline D & 65 & 0.404 & 65 & 0.136 & 64 & 0.142 & 64 & 0.148 & 66 & 0.359 & 69 & 0.156 & 73 & 0.31 & 76 & 0.156 \\
\hline $\mathrm{E}$ & 24 & 0.787 & 28 & 0.21 & 34 & 0.291 & 33 & 0.25 & 38 & 0.19 & 45 & 0.242 & 54 & 0.478 & 56 & 0.254 \\
\hline $\mathrm{F}$ & 103 & 1.253 & 105 & 0.267 & 107 & 0.419 & 110 & 0.419 & 110 & 0.444 & 120 & 0.461 & 132 & 0.535 & 133 & 0.4 \\
\hline G & 39 & 0.428 & 42 & 0.138 & 42 & 0.122 & 43 & 0.265 & 45 & 0.349 & 51 & 0.203 & 51 & 0.277 & 54 & 0.159 \\
\hline $\mathrm{H}$ & 5 & 0.258 & 5 & 0.287 & 7 & 0.35 & 8 & 0.227 & 8 & 0.712 & 9 & 0.669 & 9 & 0.746 & 8 & 0.357 \\
\hline I & 27 & 0.717 & 30 & 0.167 & 34 & 0.182 & 40 & 0.184 & 45 & 0.476 & 57 & 0.351 & 63 & 0.384 & 69 & 0.242 \\
\hline $\mathrm{K}$ & 85 & 0.539 & 93 & 0.342 & 99 & 0.324 & 107 & 0.232 & 114 & 0.346 & 117 & 0.218 & 122 & 0.407 & 122 & 0.16 \\
\hline $\mathrm{L}$ & 11 & 0.457 & 10 & 0.131 & 13 & 0.222 & 13 & 0.252 & 15 & 0.314 & 18 & 0.465 & 17 & 0.423 & 18 & 0.317 \\
\hline $\mathrm{M}$ & - & - & 1 & 0.381 & 3 & 0.241 & 3 & 0.236 & 3 & 0.333 & 6 & 0.212 & 6 & 0.318 & 6 & 0.236 \\
\hline $\mathrm{N}$ & 11 & 0.224 & 12 & 0.193 & 13 & 0.187 & 13 & 0.149 & 13 & 0.516 & 14 & 0.249 & 18 & 0.445 & 18 & 0.162 \\
\hline $\mathrm{P}$ & 1 & 0.401 & 1 & 0.057 & 1 & 0.265 & 1 & 0.172 & 1 & 0.418 & 1 & 0.289 & 1 & 0.334 & 1 & 0.296 \\
\hline $\mathrm{Q}$ & 2 & 0.959 & 2 & 0.473 & 2 & 0.131 & 2 & 0.052 & 2 & 1.988 & 1 & 0.797 & 2 & 1.054 & 2 & 0.18 \\
\hline $\mathrm{R}$ & 12 & 0.615 & 13 & 0.366 & 14 & 0.199 & 12 & 0.161 & 13 & 0.656 & 20 & 0.294 & 22 & 0.421 & 25 & 0.228 \\
\hline$S$ & 23 & 0.577 & 21 & 0.182 & 20 & 0.183 & 21 & 0.179 & 21 & 0.429 & 22 & 0.217 & 23 & 0.472 & 24 & 0.172 \\
\hline
\end{tabular}


Specific to the statistical status of the average real earnings management of the listed companies in various industries in Table 2 in each year, the highest degree of real earnings management in 2007 was wholesale and retail (F) industries, and the lowest was in the water conservancy, environment and public facilities management $(\mathrm{N})$ industries; The highest degree of real earnings management in 2008 was health and social work (Q) industries, and the lowest was education $(\mathrm{P})$; the highest degree of true earnings management in 2009 was wholesale and retail $(\mathrm{F})$ industries, and the lowest was Transportation, warehousing and postal services (G) industries; the highest degree of real surplus management in 2010 is wholesale and retail (F) industries, the lowest is health and social work (Q) industries; the highest degree of real surplus management in 2011 is health And social work (Q) industries, the lowest is the construction (E) industry; in 2012, the highest degree of real earnings management is the health and social work (Q) industry, the lowest is the production and supply of electricity, heat, gas and water( D) industries; The highest degree of real earnings management in 2013 was health and social work (Q) industries, and the lowest was transportation, warehousing and postal services (G) industries; 2014 real earnings Management is the highest level of wholesale and retail trade (F) industries, the lowest is the lowest in agriculture, forestry, animal husbandry and Fishery (A) industries.

As for the real surplus management status of various industries in different years, among agriculture, forestry, animal husbandry and fishery (A) industries, the real surplus management degree was the highest in 2011, reaching 0.516, and the real surplus management degree was the lowest in 2010, only 0.149 ; In the mining (B) industry, the real earning management degree in 2007 was the highest, reaching 0.808, and the real earning management degree in 2010 was the lowest, only 0.227 ; in manufacturing (C) industry, the real earning management degree was the highest in 2007, reaching 0.835 , the lowest level of real earnings management in 2010 was only 0.117 ; of the electricity, heat, gas and water production and supply (D) industries, the highest level of real earnings management in 2011 was 0.418 , and the degree of real earnings management in 2008 The lowest is only 0.057 ; in the construction (E) industry, the real earning management degree is the highest in 2007, reaching 0.787 , and the real earning management degree in 2008 is the lowest, only 0.136; in the wholesale and retail (F) industries, the 2007 The real earning management degree is the highest, reaching 1.253, and the real earning management degree is the lowest in 2009, only 0.122; in transportation, warehousing and logistics $(\mathrm{G})$ industries, 2012 The real earning management degree is the highest, reaching 0.465 , and the real earning management degree is the lowest in 2008, only 0.131 ; in accommodation and catering $(\mathrm{H})$ industries, the real earning management degree is the highest in 2013 , reaching 0.407 , and the real earning management degree in 2014 The lowest is only 0.160; in the information transmission, software and information technology service (I) industries, the real earning management degree is the highest in 2007, reaching 0.717, and the real earning management degree in 2014 is the lowest, only 0.172; real estate (K) industry Among them, the real earning management degree in 2011 was the highest, reaching 0.656 , and the real earning management degree in 2010 was the lowest, only 0.1612; in the leasing and business service (L) industries, the real earning management degree in 2011 was the highest, reaching 0.476, 2008 The annual real earning management degree is the lowest, only 0.167; of scientific research and technical service (M) industries, the real earning management degree is the highest in 2013, reaching 0.478, and the real earning management degree in 2011 is the lowest, only 0.190; In the environment and public facilities management $(\mathrm{N})$ industries, the real earning management level was the highest in 2012, reaching 0.515 , and the real earning in 2014 The lowest degree of management is only 0.204; the education $(\mathrm{P})$ industry has the highest degree of real earnings management in 2007 , reaching 0.401 , and the lowest degree of real earnings management in 2014 is only 0.217 ; health and social work (Q) industries, The highest level of real earnings management in 2011 reached 1.988, and the lowest level of real earnings management in 2010 was only 0.052. Among the culture, sports and entertainment (R) industries, the highest level of real earnings management in 2007 reached 0.615 in 2008 . The lowest level of real earnings management is 0.267 ; in others(S), the highest level of real earnings management in 2007 reached 0.577, and the lowest degree of real earnings management in 2012 was only 0.212 . 


\section{Industry Differences and Real Earnings Management}

\subsection{Nonparametric Test Results}

Table 3. Kruskal-Wallis H test results for industry differences

\begin{tabular}{cc}
\hline Year & Kruskal-Wallis H Test Results For Industry Differences \\
\hline 2007 & $4.984^{* * *}$ \\
\hline 2008 & $2.006^{* *}$ \\
\hline 2009 & $3.562^{* * *}$ \\
\hline 2010 & $3.126^{* * *}$ \\
\hline 2011 & $2.277^{* * *}$ \\
\hline 2012 & $4.113^{* * *}$ \\
\hline 2013 & $2.010^{* *}$ \\
\hline 2014 & $3.647^{* * *}$ \\
\hline $2007-2014$ & $11.081^{* * *}$ \\
\hline
\end{tabular}

Note: $* * *, * *$ and $*$ represent significance tests at $1 \%, 5 \%$, and $10 \%$ confidence levels, respectively.

Table 3 shows the non-parametric test results of the differences in real earnings management in different years and in different industries. On the whole, the average earnings management of different industries show obvious differences, which can pass the significance test of the conventional confidence level, which shows that there is a difference in the degree of real earnings management manipulated by listed companies in different industries. From the perspective of the non-parametric test status of each year, there are also obvious industry differences in real earnings management in each year, and they can also pass the significance test of conventional confidence levels, which shows that Chinese listed companies have a true earnings management Not only are there obvious industry differences, but the differences are also stable.

\subsection{Regression Test Results}

Table 4. Regression test results of industries differences

\begin{tabular}{ll}
\hline Industries & Test Result \\
\hline$A$ & $-0.123(0.038)^{* * *}$ \\
\hline$B$ & $0.034(0.028)$ \\
\hline$D$ & $-0.120(0.023)^{* * *}$ \\
\hline$E$ & $-0.031(0.030)$ \\
\hline$F$ & $0.166(0.018)^{* * *}$ \\
\hline$G$ & $-0.101(0.028)^{* * *}$ \\
\hline$H$ & $0.121(0.068)^{*}$ \\
\hline$I$ & $0.001(0.028)$ \\
\hline$K$ & $-0.039(0.019)^{* *}$ \\
\hline$M$ & $-0.017(0.048)$ \\
\hline$N$ & $-0.154(0.097)^{*}$ \\
\hline$P$ & $-0.087(0.049)^{*}$ \\
\hline
\end{tabular}




\begin{tabular}{ll}
\hline$Q$ & $0.227(0.133)^{*}$ \\
\hline$R$ & $-0.017(0.045)$ \\
\hline$S$ & $-0.020(0.039)$ \\
\hline $\ln ($ Size $)$ & $-0.055^{* * *}$ \\
\hline$R O A$ & $0.521^{* * *}$ \\
\hline Debt & $0.250^{* * *}$ \\
\hline$H 10$ & $0.437^{* * *}$ \\
\hline$F n$ & 0.003 \\
\hline$C$ & $1.326^{* * *}$ \\
\hline$R^{2}$ & 0.034 \\
\hline$F$ & $19.780^{* * *}$
\end{tabular}

Note: ***,**, and * represent significance tests at $1 \%, 5 \%$, and $10 \%$ confidence levels, respectively. The standard error values of the coefficient values are in parentheses.

From the regression results in Table 4, the 16 comparative industries included in the sample, the virtual variable test results of 9 industries can pass the significance test of conventional confidence levels, including agriculture, forestry, animal husbandry, and fishery (A ) industries, Electricity, heat, gas and water production and supply (D) industries, wholesale and retail $(F)$, transportation, warehousing and logistics $(\mathrm{G})$ industries, accommodation and catering $(\mathrm{H})$ industries, real estate $(\mathrm{K})$ industries, Scientific research and technical service(M) industries, water conservancy, environment and public facilities management $(\mathrm{N})$ industries and health and social work $(\mathrm{Q})$ industries, show that the real earning management degree of these industries is obviously different from other industries. At the same time, in the regression test results in Table 3.8, the $\mathrm{R} 2$ value is only 0.034 , which shows that the industry difference can explain the real earnings management difference of Chinese listed companies to an extent of about $3.4 \%$, which is the same as using the same method to test the reduction of major shareholders. (0.335, Cao Guohua and Lin Chuan, 2013), the company's capital structure (0.095, Guo Pengfei and Yang Chaojun, 2003), cash dividends (0.110, Li Zengfu and Tang Chunyang, 2004) and the results of private control rights (0.172, Lin Chaonan et al., 2006), etc. This is significantly lower than that, which also shows that other factors such as the company's financial characteristics and governance characteristics are the main factors that dominate the real earnings of Chinese listed companies.

\section{Conclusion}

This article examines the industry differences in the real earnings management behavior of listed companies in China. The study finds that listed companies in the health and social work $(\mathrm{Q})$ industries have the highest degree of real earnings management, and that electricity, heat, gas and water production and supply (D) industries show the lowest level of real earnings management, and there are obvious industry differences in real earnings management among Chinese listed companies. The real earning management levels of listed companies in different industries are significantly different, and this difference is relatively stable.

The empirical evidence in this paper shows that there are industry differences in the real earnings management of Chinese listed companies. So why are listed companies conducting real earnings management? There are also some questions which scholars focus on, such as the desire to obtain direct market returns, the special purpose of management, etc. From the perspective of behavioral finance, including the anchoring effect and limited rationality, can also explain earnings management behavior, and whether these factors or theories can explain the real earnings management behavior of listed companies should be the issue of concern for further research.

\section{Acknowledgement}

The authors gratefully acknowledge supported by Chongqing Social Science Planning Project (Grant No. 2018BS61) of Chongqing federation of Social Science Circles. 


\section{References}

Cai, Ch., Zhu, R., \& Xie, L. F. (2011). Review of research on real earnings management. Economics Dynamics, (12), 125-130.

Cao, G. H., \& Lin, Ch. (2013). Industry differences and shareholder reduction behavior. China's Circulation Economy, (1), 117-122.

Chen, W. Ch. (2013). Economic cycle, industry cycle and earnings management degree-Empirical evidence from Chinese listed companies. Nankai Management Review, 16(3), 26-35.

Clarke, R. N. (1989). SICs as Delineators of Economic Markets. Journal of Business, 30(12), 17-31. https://doi.org/10.1086/296449

Cohen, D. A., Dey, A., \& Lys, T. Z. (2008). Real and Accrual based Earnings Management in the Pre- and Post-Sarbanes-Oxley Periods. The Accounting Review, 83(3), 757-787. https://doi.org/10.2308/accr.2008.83.3.757

Guenther, D. A., \& Rosman, A. J. (1994). Differences Between COMPUSTAT and CRSP SIC Codes and Related Effects on Research. Journal of Accounting and Economics, 18(1), 115-128. https://doi.org/10.1016/0165-4101(94)90021-3

Guo, P. F., \& Sun, P. Y. (2003). Industry characteristics of capital structure: Empirical research based on Chinese listed companies. Economic Research, 38(5), 66-73.

Guo, P. F., \& Yang, Ch. J. (2003). Corporate performance and stock price returns: an empirical analysis based on industry characteristics. Securities Market Herald, (7), 74-76.

Hu, Y. P., \& Luo, J. K. (2010). Investigation on industry differences of IPO earnings management methods of listed companies. Accounting Monthly, (20), 7-9.

Jin, Y. (2011). An empirical study on continuous R \& D investment and company performance based on industry differences. Shandong Social Sciences, (10), 157-160.

Kahle, K. M., \& Walkling, R. A. (1996). The Impact of Industry Classifications on Financial Research. Journal of Financial and Quantitative Analysis, 31(9), 309-335. https://doi.org/10.2307/2331394

Li, B., Zhang, J. R., \& Guo, H. T. (2009). Study on the relationship between accounting flexibility and earnings management of real activities. Manage Comments, 21(6), 99-107.

Li, W. L., Chen, L. Y., \& Lu, H. L. (2011). Earnings restatement and manipulation of real activities-Taking the restatement company with high earnings as an example. Audit and Economic Research, (4), 69-76.

Li, Z. F., \& Tang, Ch. Y. (2004). An Empirical Study on the Diversity of China's Listed Companies' Dividend Distribution Industry. Contemporary Economic Science, (5), 71-75.

Lin, C. N., Liu, X., \& Hao, Y. (2006). Industry characteristics and private benefits of control: empirical evidence from listed companies in China. Economic science, (3), 61-72.

Quan, X. F., Teng, M. H., \& Wu, Sh. N. (2010). Industry Characteristics and Cash Dividend Policy-Based on the Empirical Research of Chinese Listed Companies from 2004 to 2008. Financial Research, (8), 122-132.

Roychowdhury, S. (2006). Earnings Management through Real Activities Manipulation. Journal of Accounting and Economics, 42(3), 335-370. https://doi.org/10.1016/j.jacceco.2006.01.002

Scott, D. F., \& Martin, J. D. (1975). Industry Influence on Financial Structure. Financial Management, 4(1), 67-73.

Wang, L. L. (2013). Real activity earnings management and cost of equity capital. Management Science, 26(5), 87-99.

Zhou, J., Meng, Y. Y., \& Liu, X. Y. (2009). Research on the relationship between the company's cash holdings, industry differences, and shareholding structure-Comparison of information technology and non-information technology listed companies. Economics and Management Research, (8), 28-36.

Zhou, X. F., \& Zhou, Q. L. (2014). Product market power, industry competition and company earnings management: based on empirical evidence of Chinese listed companies. Accounting Research, 24(8), 60-66. 